\title{
Evaluation of the efficiency of enterprises in the transition to alternative (helio) energy sources
}

\author{
Iryna Perevozova* A; Tetiana Maksimenko A; Svitlana Bondarenko ${ }^{\text {B }}$ \\ A Ivano-Frankivsk National Technical University oil and gas, 15, Karpatskaya, Ivano-Frankivsk, 76000, Ukraine

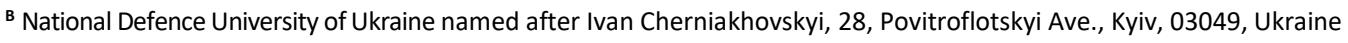

Received: August 17, 2020 | Revised: August 27, 2020 | Accepted: August 31, 2020

JEL Classification: Q42, Q43, Q47, Q48.

DOI: $10.33445 /$ sds.2020.10.4.17

\begin{abstract}
The aim of the article is to study the main approaches and develop a methodology for assessing the efficiency of enterprises in the transition to alternative (helio) energy sources. The concepts of the 'energy efficiency' and the 'energy saving' are the main characteristics of efficient use of energy resources. The term "energy efficiency" is a resultant indicator that captures the achieved level of efficiency of consumption and use of fuel and energy resources in the process of enterprise activity. The concept of 'energy saving' is a process indicator that indicates the way to achieve energy efficiency (implementation of a set of measures) of resource conservation in the enterprise. It is established that the key indicator for assessing the efficiency of the energy consumption system is the energy intensity indicator, the reduction of which should be considered as one of the main tasks in order to increase the efficiency of the enterprise.

It is proved that the transition of an industrial enterprise to alternative (helio) energy sources is a guarantee of reducing its energy intensity. Therefore, the issues of implementation of energy saving programs are relevant for industrial enterprises. Energy saving measures will help reduce costs at the enterprise, conserve natural resources. The study found that solar energy in Ukraine in 2019 shows a bright positive trend. The 'green tariff' was officially received by stations with a total capacity of $3537.382 \mathrm{MW}$, which is 5.48 times higher than in 2018. In 2019, the capacity of industrial solar power plants was put into operation 3.5 times more than in all previous years. The amount of electricity produced by industrial plants, in 2019, is 2.66 times higher than in 2018.

The transition to alternative energy sources for industrial enterprises is a rather complex technological task, which requires methodological developments for the optimization of energy resources to maximize the efficiency of enterprises. A method for assessing the efficiency of the enterprise in its transition to alternative (helio) energy sources based on the use of production functions and factor models, which include the entire evaluation apparatus and a set of indicators of efficiency (appropriateness) of resource use, i.e. resource conservation. This method of assessing the performance of the enterprise is based on the use of the Cobb-Douglas production function, which allows to justify the decision on the feasibility of the use of production resources and to adjust the deviations of the spent resources from the normative values.
\end{abstract}

Key words: alternative (helio) energy sources, solar energy, industrial enterprises, enterprise efficiency, energy efficiency, energy saving, energy intensity.

\section{Introduction}

The concept of sustainable development is the latest philosophy of solving existing environmental problems (Cohen \& Winn 2007). Within the circular economy, socially significant problems are relevant for business: renewable energy, fuel cells, green building, natural foods, carbon emissions, etc. (Dean \& McMullen 2007). For industrial enterprises, switching to

\footnotetext{
* Corresponding author: Head of the Department, D.Sc., (Economics), professor, e-mail: perevozova@ukr.net, ORCID: 0000-0002-3878-802X
} 
renewable energy is not only a duty, not just a challenge, but also an opportunity that gives a new impetus to business (Austin et al., 2006). Thus, $95 \%$ of executives of large American corporations say that green energy creates additional opportunities for business. Of these, $30 \%$ already have practical experience in implementing the provisions of the circular economy in their activities, and $77 \%$ of respondents plan to implement such principles in their companies in the next 5 years (Going Circular).

The concept of green energy is based on the transition to sustainable development, which includes promoting investment in natural capital, solving energy problems, optimal resource management, transition to more efficient, environmentally friendly and resourcesaving technologies aimed at reducing pollutant emissions, stopping resource depletion, mitigation of the effects of climate change, etc. (Georgeson et al., 2014).

Support for renewable energy is a priority for energy development in the vast majority of European Union countries, especially given the program of action of the European Green Agreement to achieve a climate-neutral economy by 2050 (European Green Deal).

Technological improvements that are characteristic of economic innovation do not reduce the cost of energy and energy resources. This statement is known as the 'Jevons paradox' - the effect of energy efficiency reduces the cost of energy use, thus encouraging its wider use in other areas and industries. Improving energy efficiency leads to increased economic growth. At the micro level (market separately), increasing energy efficiency usually leads to lower energy consumption. However, at the macro level, this type of economic growth will usually increase energy use in all sectors of the economy. That is, technological progress increases energy efficiency and will tend to increase overall energy consumption (Ruzzenenti et al., 2019).

According to the concept of Makarovs energy saving policy, the energy intensity of production and services has, at different stages of development of economic systems, upward or downward trends, depending on a set of circumstances (Lukaschuk et al., 2018). Therefore, depending on the demands of society, measures are taken to save energy resources in the production and conversion of energy, its use in production and in meeting non-productive needs. As a means of improving the overall efficiency of the economy, energy saving policies include measures to replace expensive and exhaustible types of energy resources with more efficient and large-scale ones. In this case, the final energy savings can be achieved through measures to improve the energy economy of consumers, i.e. by increasing the efficiency of energy-using equipment, requiring program activities within enterprises (Bondarenko, 2019). The main areas of energy efficiency are: reducing the energy intensity of final energy production through progressive changes, the introduction of advanced technological processes, improving intersectoral links and the structure of the national economy, improving production organization, etc. (Bondarenko \& Zerkina, 2019).

There is a direct connection between the effectiveness of the implementation of the strategy of energy policy of the state with a separately functioning enterprise at the level of both structural and functional approaches to solving the problem of energy efficiency and energy saving (Energy efficiency 101).

The most important factors in improving the efficiency of enterprises are the ratio of intensive and extensive factors, as well as the relative efficiency and availability of energy resources, the ratio of energy and labor costs, energy and materials (Energy management for business).

An important element of influence on industry is the regulation of technical and economic conditions of production through active state technological policy, which provides the greatest opportunities for state incentives to save energy in industry. According to numerous studies, the level of implementation of energy efficient equipment is much lower than the level that is cost-effective for energy consumers (IPCC, 2007; McNeil et al., 2008). Therefore, the main focus of energy efficiency policy is to 
bridge this gap (Letschert et al., 2012) by identifying and eliminating barriers to consumers from investing in energy efficient equipment. (Sathaye \& Murtishaw, 2004; Murphy \& Meier, 2011).

World practice shows the effectiveness of numerous incentive programs to overcome these barriers and accelerate the penetration of more efficient equipment (Ahern, \& Norton., 2020). For the most part, such programs are part of the national state energy efficiency policy, but programs have been created that are part of the strategies of integrated resource planning of utilities (World Energy Investment 2020).

Industrial enterprises should play a leading role in the transition to a climate-neutral economy (Energy-intensive industries). In March 2020, the European Commission presented a 'New Industrial Strategy for Europe'. The document emphasizes the important role of industrial enterprises in the transformation into a carbon-neutral economy. The industry must work not only to reduce its own carbon emissions, but also to accelerate the transition by providing affordable, clean technology solutions and developing new business models.

As part of promoting energy security and efficiency, Ukraine has sought to increase the share of renewable energy by introducing special regulatory and incentive tools, including green tariffs, and setting targets in the energy strategy (according to which, by 2035, the share of renewable energy) in the overall structure of electricity supply should be $25 \%$ ).

For a modern enterprise, reducing energy consumption and increasing energy efficiency, along with increasing productivity, are the most important indicators of efficiency and competitiveness.

Introduction of own autonomous power supply system from solar modules will allow to increase indicators of energy saving and energy efficiency of the enterprise, and also to reduce expenses for the electric power at the expense of use of solar energy as one of sources. This technology is most effective for consumers with mostly low workload - small and medium enterprises. Based on the above, it is necessary to develop the basis for the implementation of measures at industrial enterprises the most rational use and utilization of energy resources.

Problem definition. The aim of the article is to study the main approaches and develop an author's methodology for assessing the efficiency of enterprises in the transition to alternative (helio) energy sources. In the framework of this study, the following problematic issues are identified: to determine the basis for the transition of an industrial enterprise to alternative (helio) energy sources; to study modern approaches and to offer the author's technique of an estimation of efficiency of the enterprises at transition to alternative (helio) energy sources.

\section{Material and Method}

The main indicator of energy efficiency is the specific value of consumption of fuel and energy resources for the production of a unit of production for any purpose.

As indicators of efficiency of the enterprise, according to the model of production function $y=F_{1}(x, A)$, usually consider two groups of indicators - indicators of efficiency of the enterprise as a whole and indicators of efficiency of use of resources.

Consider the efficiency or return on resource use on the example of a one-factor production function $y=a x^{a}$, which reflects the dependence of output on the vector of production resources.
Indicators of return on resources are:

- the average productivity of the resource $(\lambda)$, which is determined by the formula:

$$
\lambda=\frac{y}{x} \text {; }
$$

- marginal productivity of the resource $\mu$ :

$$
\mu=\frac{d y}{d x} \text { or } \mu_{1}=\frac{\Delta y}{\Delta x}
$$

- elasticity of output by resource $E_{x}^{y}$ (percentage increase in value $y, x$ in response to an increase in value by $1 \%$ ), calculated by the formula:

$$
E_{x}^{y}=(\mathrm{dy} / \mathrm{dx}) /(\mathrm{y} / \mathrm{x}) \text { або } E_{x}^{y}=(\Delta \mathrm{y} / \Delta \mathrm{x}) /(\mathrm{y} / \mathrm{x}) .
$$

These indicators reflect the effect of resource 
use over a period of time, such as a year.

In economic theory, the concept of return on resources includes, on the one hand, output or its monetary expression (income, revenue), on the other - the amount of resources used over the same period of time to pay for them, i.e. costs. Resource efficiency involves obtaining the same amount of raw material without compromising quality while reducing resource consumption by reducing losses and waste. Thus, the factor of production is not the accumulated amount of resources, and their use for some time - interval values. The energy efficiency of the enterprise is the ratio of the obtained beneficial effect to the amount of energy consumed. Thus, energy efficiency is an indicator that reflects the ratio of the total profit derived from the use of energy resources to the total cost of using certain fuel and energy resources in the production and technological process of an industrial enterprise for the analyzed period. Improving energy efficiency means more efficient use of a certain amount of energy, which allows you to get a greater beneficial effect from the use of a unit of energy. Energy saving reflects the reduction in the amount of energy consumed required to obtain a unit of useful effect. The resulting indicator is energy consumption, which reflects the amount of energy needed to obtain a certain useful effect. In essence, energy intensity is an indicator, the inverse of energy efficiency.

Fig. 1 presents a conceptual diagram of the interdependence of enterprise efficiency and energy efficiency.

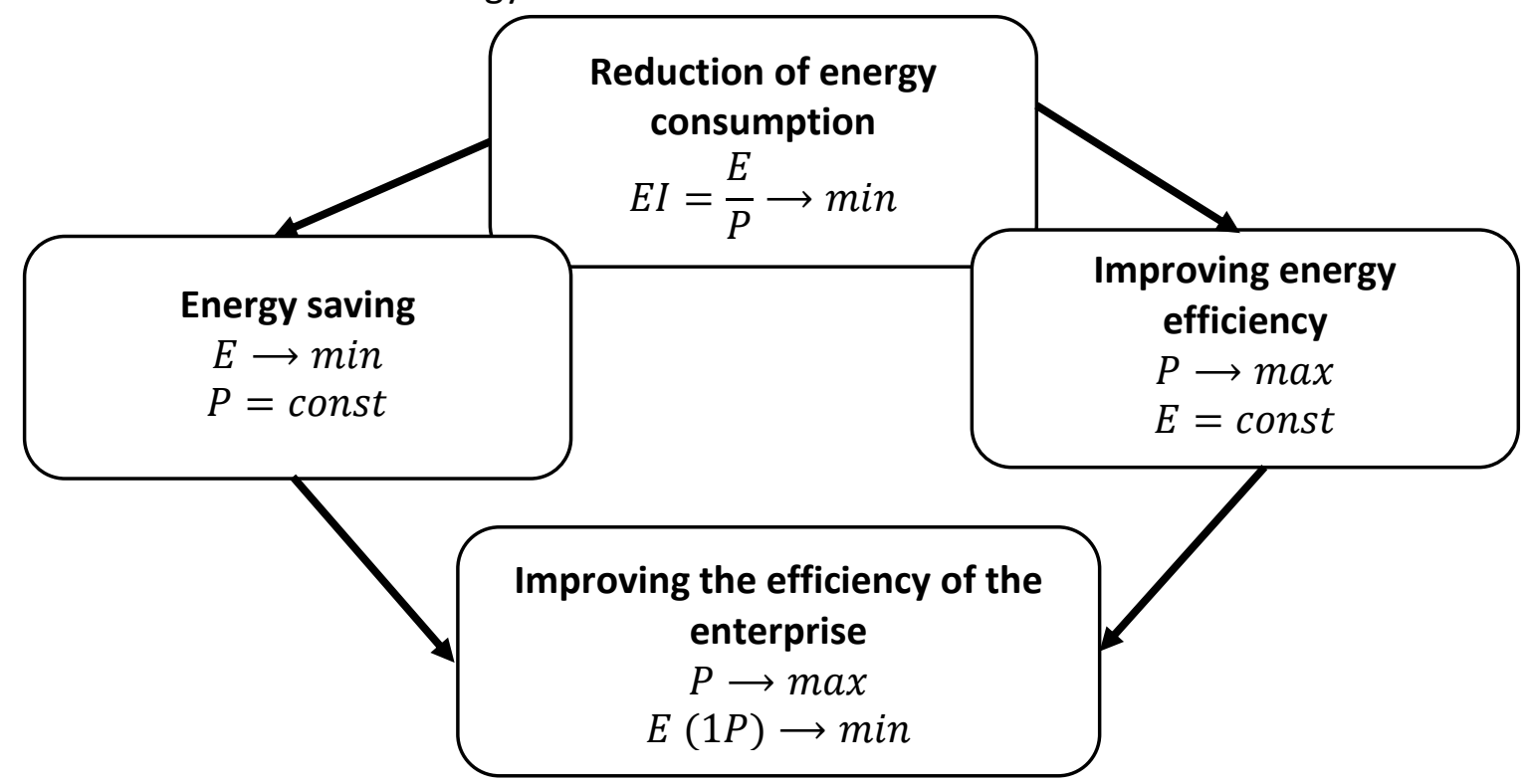

Where $P$ - the volume of products produced at the enterprise, $E$ - the amount of energy used, $E(1 P)$ - the amount of energy used per unit of output.

Figure 1 - Conceptual scheme of interdependence of enterprise efficiency and its energy efficiency

The terms 'energy saving' and 'energy efficiency' are interdependent categories, with 'energy efficiency' being the resulting indicator that captures the achieved level of efficiency of consumption and use of fuel and energy resources in the process of enterprise activity. The concept of 'energy saving' is a process indicator that indicates the way to achieve energy efficiency (implementation of a set of measures) of resource conservation in the enterprise.

The concepts of 'energy saving' and 'energy efficiency' are the main characteristics of efficient use of energy resources

Thus, the key indicator for assessing the efficiency of the energy consumption system is the energy intensity indicator, the reduction of which should be considered as one of the main tasks in order to increase the efficiency of the enterprise. 


\section{Results and discussion}

The technological world needs more and more energy. All countries maintain and develop a stable traditional generation - coal and oil and gas thermal power plants, hydropower plants and nuclear power plants. Alternative energy sources are seen as an important tool to reduce the environmental burden of energy production and consumption. These sources can contribute to ensuring the reliability of energy supply when replacing imported fossil fuels. Dynamicsproduction and consumption of the main types of energy resources in Ukraine are presented in Table 1.

Table 1 - Production and consumption of main types of energy resources in 2008, 20132018(in million tons of so-called oil equivalent). (Statistical Review of World Energy, 2020)

\begin{tabular}{|l|c|c|c|c|c|c|c|}
\hline \multicolumn{7}{|c|}{$\begin{array}{l}\text { Sources of } \\
\text { energy resource }\end{array}$} & \multicolumn{7}{|c|}{ Years } \\
\cline { 2 - 8 } $\begin{array}{l}\text { General } \\
\text { production }\end{array}$ & 2008 & 2013 & 2014 & 2015 & 2016 & 2017 & 2018 \\
\hline Oil & 3999 & 412794 & 12913 & 13058 & 12992 & 13304 & 13838 \\
\hline Gas & 2605 & 2892 & 2950 & 3011 & 3045 & 3162 & 3326 \\
\hline Coal & 2410 & 3978 & 3966 & 3861 & 3661 & 3755 & 3917 \\
\hline Ghydroelectricity & 737 & 858 & 879 & 879 & 909 & 920 & 949 \\
\hline $\begin{array}{l}\text { Nuclear power } \\
\text { plants }\end{array}$ & 620 & 564 & 575 & 583 & 592 & 597 & 611 \\
\hline $\begin{array}{l}\text { Renewable } \\
\text { energy sources }\end{array}$ & 124 & 263 & 320 & 369 & 419 & 490 & 561 \\
\hline Consumption & 11708 & 12820 & 12940 & 13047 & 13229 & 13475 & 13865 \\
\hline
\end{tabular}

The current state of electricity production from alternative sources in Ukraine is presented in Figure 2.

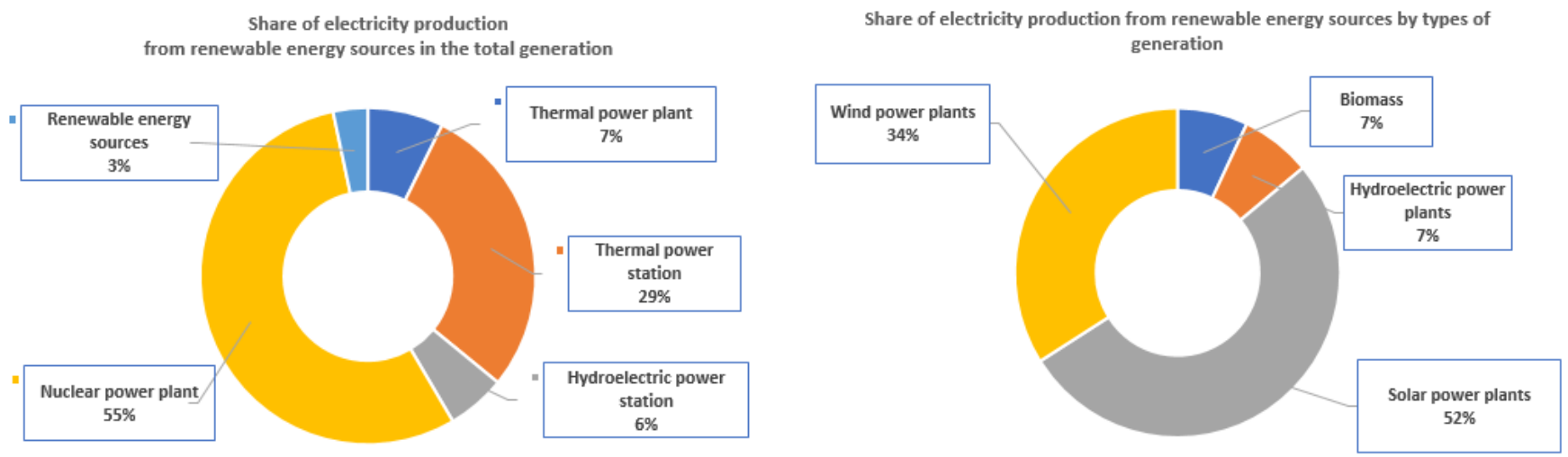

Figure 2 - Electricity generation from renewable energy sources, Ukraine, 2019 (Energy market)

In Ukraine, the share of renewable energy insignificant. Excluding hydropower, in recent has increased in recent years, but still remains years the share of renewable energy sources in 
the structure of energy resources of Ukraine was $3-4 \%$. At the same time, biofuels, wind and solar energy are becoming increasingly popular. Solar energy is captured in various ways, the most common of which are photovoltaic solar panels, which convert sunlight into useful electricity. This relatively new way of generating electricity developed rapidly in the mid-2000s, when EU countries began to implement policies to reduce their dependence on carbon during electricity generation.

The capacity of industrial solar power plants has been installed in Ukraine

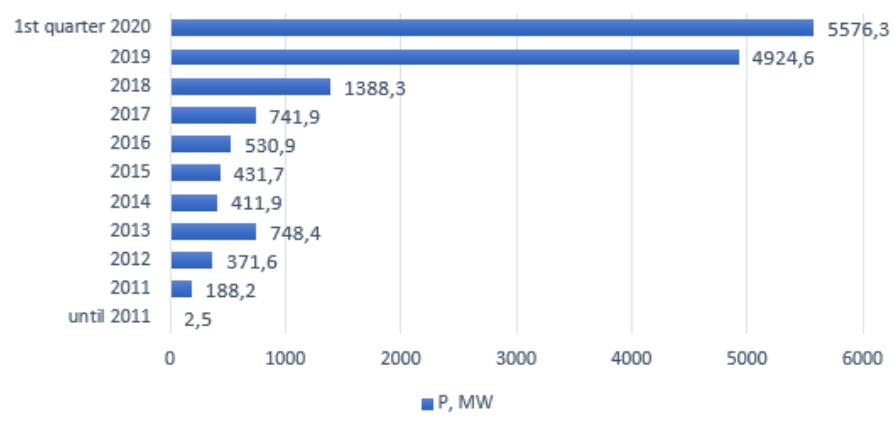

According to the forecast of the European Solar Energy Association (SolarPower Europe), already in 2022, the installed capacity of the world's solar energy may exceed $1,000 \mathrm{GW}$, so the share of solar generation in the structure of electricity production in the world will reach $5 \%$.

Solar energy is one of the largest and most promising components of alternative energy (Fig. 3).

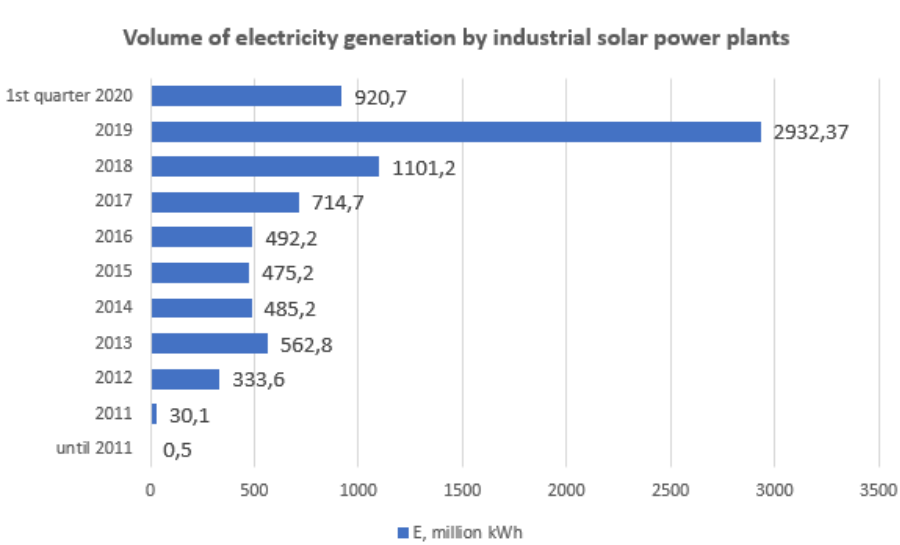

Figure 3 - Electricity generation from solar radiation energy by industrial solar power plants, Ukraine 2011-2020 (Energy market)

Solar energy in 2019 shows a bright positive trend. Thus, as of 01.01.2020, the total installed capacity of industrial solar power plants in Ukraine reached 4924,610 MW. At the same time, for 12 months of 2019, the 'green tariff' was officially received by stations with a total capacity of $3537.382 \mathrm{MW}$, which is 5.48 times higher than in 2018 (645.688 MW). In 2019, the capacity of industrial solar power plants was put into operation 3.5 times more than in all previous years. As for the amount of electricity produced by industrial plants, in 2019 it amounted to 2932.37 million $\mathrm{kWh}$, which is 2.66 times higher than in 2018 (1101.16 million kWh). In this case, based on the estimated value of average annual consumption per household, which is equal to $2000 \mathrm{kWh}$, the energy produced by solar power plants is sufficient to meet the needs of 1.466 million households.

Industrial solar power plants in Ukraine are a very promising contribution. Among developing countries, Ukraine ranked 10th in terms of investments made during the year $-\$ 2.1$ billion, and 8 th - in terms of attractiveness of investments in renewable energy sources.

However, for the development of solar energy in Ukraine, 2019 was a breakthrough year. According to statistics, only in the first half of 2019, 1.3 billion euros were invested in domestic alternative energy. The businessmen invested the most money in the photovoltaic industry. The total capacity of solar power plants installed in the country now exceeds $2.6 \mathrm{GW}$. In 2019, the Law 'On Green Tariff' was signed, which strongly encourages alternative energy. Thus, on your own land you can install a station with a capacity of up to $30 \mathrm{~kW}$. This allows homeowners to become independent of the central electricity supply and reduce the cost of utilities (Solar energy). The potential of solar energy in Ukraine is such that high-capacity industrial solar power plants (10 MW and more) successfully supply electricity to small and medium enterprises.

In economics, the concept of energy intensity of GDP is the ratio of total energy consumption to GDP.

According to the International Energy Agency 
(IEA), Ukraine is a country that is one of the most inefficient consumers of energy. Ukraine's energy intensity, measured as the ratio of total primary energy supply to GDP, is 10 times higher than the OECD average. If the purchasing power parity is adjusted, Ukraine consumes about 3.2 times more energy per unit of GDP than the OECD average. The amount of energy used to produce a unit of goods and services (i.e. per unit of GDP) exceeds the level of: the United Kingdom -4.8 times; Turkey -3.8 times; Poland - 3 times; Belarus 1.8 times; the average value for the European Union is 3.8 times; the average value for the world -2 times.
Ukraine is one of the most energy-intensive countries in the world and one of the few countries in Europe where there is no state support for energy efficiency and active encouragement (stimulation) of domestic enterprises in the direction of improving resource efficiency. As a result, the level of harmful emissions into the atmosphere from stationary industrial sources is quite high $(92.3 \%$ of the total emissions - according to 2017 statistics). However, in recent years there has been a reduction in harmful emissions from industry - by $36.8 \%$ in 2017 , compared to 2010 (Fig. 4).

\section{$\rightarrow$ Industrial production}

$\rightarrow$ Harmful emissions into the atmosphere from industrial enterprises

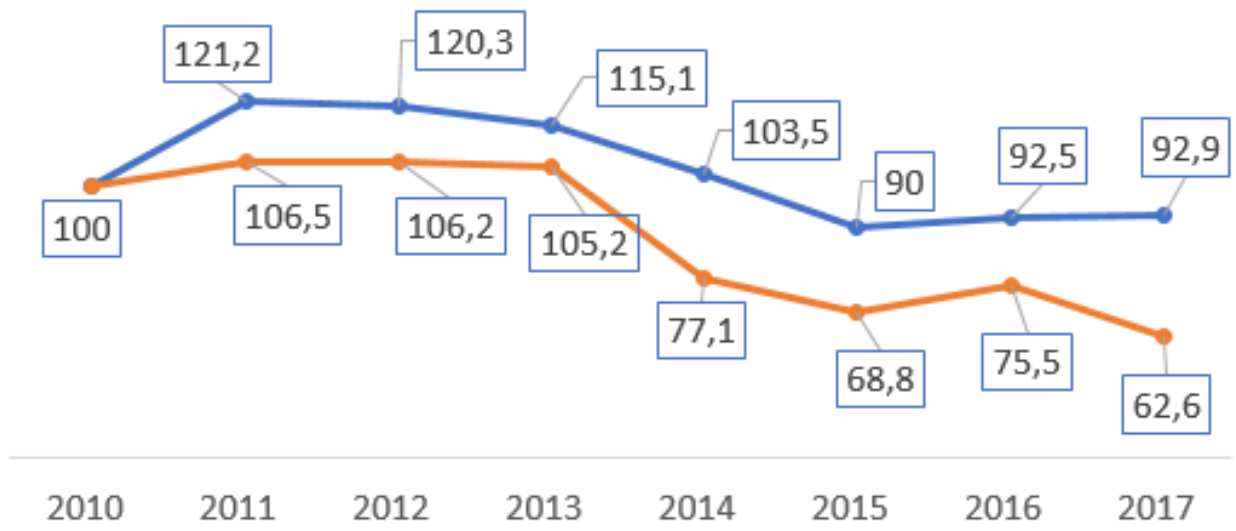

Figure 4 - Interdependence of growth rates of industrial production and harmful emissions into the atmosphere from industrial enterprises in Ukraine, \% by 2010

The largest air pollution is caused by mining enterprises - $20.1 \%$ (of total emissions by industrial enterprises), processing industry $36.7 \%$ (including metallurgy $-30.3 \%$ ), electricity production $-43.1 \%$. These are mostly large industry complexes of Ukrainian industry. Due to economic difficulties, environmental protection measures are very slow at enterprises. The main reasons for the high energy consumption of products are:

- wear and tear of power plant equipment, low efficiency of conversion of primary energy into electricity;

- uneconomical electric lighting systems;

- lack of efficient calculation of costs for primary energy production and energy production;
- morally and physically obsolete technological equipment;

- inflated prices for energy and energy carriers;

- lack of material interest in the introduction of energy-saving technologies and energy saving.

The natural catalyst for this process is rising resource prices. Thus, according to a survey of small and medium enterprises (Research \& Branding Group), more than $80 \%$ of them implemented resource-efficient measures precisely because of changes in prices for energy and raw materials. For example, a study of 410 enterprises in Poltava region showed that the most popular measures were to save energy, one of the most valuable resources (Fig. 5). 


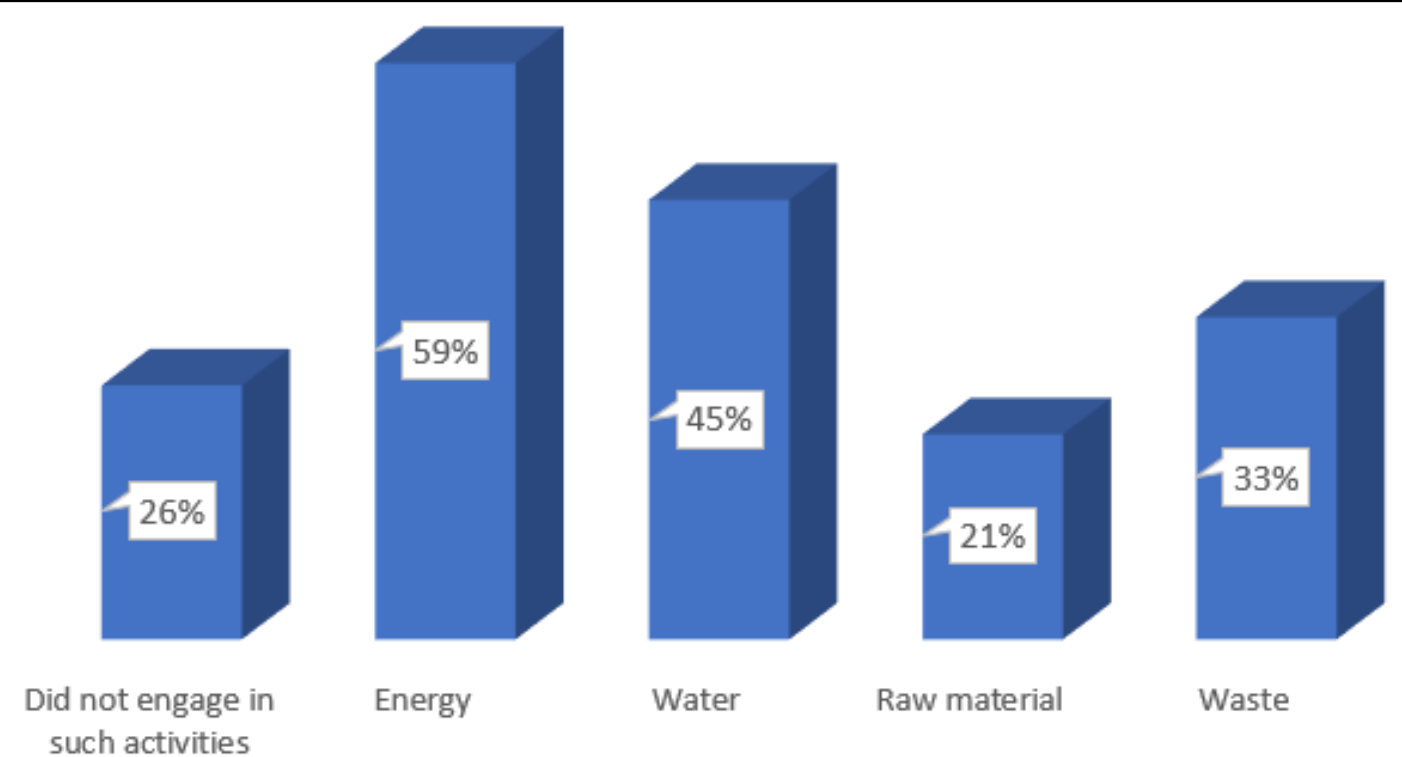

Figure 5 - Priority areas of activity of Ukrainian enterprises to improve resource efficiency (Research \& Branding Group)

At the same time, $81.1 \%$ of enterprises noted that they do not receive external support for the implementation of their actions on the environment and efficient use of resources.

The negative consequences of the lack of investment of Ukrainian producers in energy efficient technologies are as follows:

- Enterprises are becoming uncompetitive. An industry that does not invest in energy efficiency today will not be able to sell its product on world markets tomorrow. The higher the cost of production, the higher will be the final price of the goods for the buyer. Thus, Ukrainian companies are becoming less competitive in foreign markets, so they lose markets to more efficient producers.

- The state has to import energy. High energy intensity of enterprises leads to excessive energy consumption throughout the country. As its own energy production is not enough to meet the country's needs, Ukraine has to import it. At the end of 2018, Ukraine imported $36 \%$ of all energy it needed. In today's geopolitical environment, dependence on imported energy resources means political and economic danger.

According to the State Statistics Service, industry consumes $32 \%$ of the country's energy. At the same time, the industry has a 40 percent potential for energy efficiency. That is, manufacturing companies could consume $40 \%$ less energy per unit of output if they upgraded equipment and cared about energy conservation.

- Climate change. As a result of greenhouse gas emissions from the combustion of gas, coal and other fossil fuels, the planet is warming. The introduction of efficient clean technologies in production will reduce energy consumption, which reduces $\mathrm{CO}_{2}$ emissions and counteracts climate change.

Unlike the household and budget sectors, Ukraine's industry does not have any systemic program to support energy efficiency by the state.

In EU countries, the state financially stimulates industry to save energy in two ways. The first is a scheme of energy efficiency commitments. The second - support programs: grants, reduced interest rates on loans for energy efficiency measures, tax benefits.

In the first case, the state obliges energy supply companies to achieve a certain level of energy savings from their consumers, including industrial enterprises, through the introduction of energy efficiency measures.

Each country sets its own targets for energy savings, but usually the savings are $0.5-5 \%$ of total energy consumption per year.

Energy companies report annually to the state on how they have fulfilled these obligations. If the savings plan is not fulfilled companies pay a penalty. Its size depends on 
how much energy they could not save.

Energy supply companies reduce energy consumption by introducing energy efficiency measures themselves or by rewarding consumers for implementing such measures (introducing a system of 'white certificates').

If the company has implemented measures, it receives a certificate for the achieved savings and can sell it to the energy supply company directly or on the stock exchange. This stimulates energy savings and reduces its use.

Ensuring energy savings through an EU commitment scheme is regulated by law. It defines the administrator, the responsibilities of energy supply organizations, the methods of saving, the system of monitoring and reporting of the government.

Funds for 'white certificates' and the implementation of measures are accumulated due to the investment component in the energy tariff. This is an additional $1.5-2 \%$ to the tariff. There is a debate that the scheme is dishonest: everyone pays, but not everyone spends. However, every consumer has access to it. Over the years, it has proven to be effective.

Italy. The country began implementing a commitment scheme in 2001. In 2004, the tool began working. At the initial stage, the scheme operated mainly in the household sector. The share of the industrial sector began to grow in 2009 with a further strong acceleration in 2012. The not very active participation of industry in the first stage was explained by the fact that the administrative procedures of the scheme were difficult for the industry and time consuming. As a result, in 15 years, $60-70 \%$ of the total reduction in energy consumption in the country became possible due to the scheme of obligations in industry. Currently, this is the main way to stimulate energy savings in the country.

France. The state has two main instruments that stimulate energy savings: the energy efficiency commitment scheme and eco-energy credit. The commitment scheme in France was introduced in 2005 and formed over 15 years in four stages. Each time we improved the procedure and set stricter requirements for the amount of savings for consumers. For example, commitments on savings in the fourth stage (2018-2020) tripled compared to the first and second stages (2006-2014). At present, the commitment scheme in France is a central element of public policy on energy efficiency in consumers. $23 \%$ of savings there have been achieved due to the industrial sector.

Eco-energy loans are loans for small and medium enterprises without collateral at a reduced rate, which must be repaid within five years. Funds are spent on energy efficient equipment. The program has been operating since 2010.

Germany. The country has been implementing energy efficiency programs since 1994. During this time, some of them ended and transformed. In 2020, the program 'Guidelines for Federal Financing of Energy Efficiency in Business - Grants and Credits' was launched. This is the result of the reorganization of several previous programs, which the state has simplified and merged.

The program to support energy efficiency of enterprises in Germany is implemented through two institutions. Low-interest loans are provided by the State Development Bank (KfW) and investment grants are provided by the Federal Office for Economic Affairs and Export Control (BAFA).

In Poland the National Fund for Environmental Protection and Water Management (NFOŚiGW) operates. He has introduced a number of programs to support innovation. They contribute to a resourceefficient and low-carbon economy, including in the industrial sector. The fund offers loans, subsidies and other forms of co-financing of projects. In 2011, the Law on Energy Efficiency was adopted, which introduced a scheme of energy efficiency obligations. The system started operating in 2013, but at first the procedures were too complicated. In 2016, they were simplified.

In Austria the scheme of energy efficiency commitments was introduced at the level of legislation in 2011. She started working in 2015. The country also has an environmental funding program, the Umweltförderung im Inland, introduced by the 1993 Law on Environmental 


\section{Subsidies.}

The environmental support program is one of the most important subsidies for Austrian companies with a focus on climate protection, energy saving, renewable energy sources and the prevention of air pollution. The subsidy consists of a grant that covers up to $30 \%$ of investment costs.

EU countries have accumulated considerable experience in implementing energy efficiency measures. They usually start with simple government programs to provide investment grants and low-interest loans.

As knowledge, experience, data, and institutional capacity accumulate, countries move to more sophisticated tools, such as commitment schemes, including trade in 'white certificates'.

Introduction of energy efficiency at the enterprises of Ukraine

The key to reducing energy intensity is the introduction of energy saving programs at the enterprise. Energy saving measures will help reduce costs at the enterprise, conserve natural resources. The main reason for measures to reduce energy consumption at the enterprise is the need to increase the economic efficiency of production. Most of the energy consumption in enterprises is due to the depreciation of equipment and energy loss during transportation from producer to consumer. The energy saving program must have certain goals that are clearly stated, a set of specific algorithms (procedures), their relationship and an effective management system.

The planned results of the implementation of the energy saving program are as follows:

- optimization of needs in fuel and energy resources of the concrete object for which the program of energy saving is developed;

- commissioning of specially developed energy-saving equipment, structures and materials, technical devices, which also helps to save electricity.

Advantages of solar power plants for enterprises:

- Convenience. A solar power plant is usually installed on the roofs of buildings. They mostly have a large area on which it is easy to place panels and collectors. You do not need to occupy the territory for this.

- Ability to install high-power stations. They will pay off quickly and will give a guaranteed profit for years to come.

- Financial profitability. All generated electricity is sold. There is no norm of accounting for own consumption. The green tariff is 'pegged' to the euro exchange rate, which insures investors against exchange rate risks.

- The station is installed on the protected territory. This does not require the allocation of funds.

- Businesses typically have a powerful power supply cable system. No additional cables are required when installing the station.

- Electricity and energy are available in the staff of enterprises. They can service the solar power plant.

Thus, in 2019, the 'green tariff' received 494 objects, of which 382 - terrestrial solar power plants and 112 - stations located on roofs and facades of buildings (Table 2). In 2018, only 162 industrial facilities received the 'green tariff', of which only 16 solar power plants exceeded the threshold of $10 \mathrm{MW}$ (which is 7.1 times less than in 2019).

Table 2 - The main characteristics of commissioned solar power plants in Ukraine in 2017-2019

\begin{tabular}{|c|c|c|c|c|c|c|}
\hline \multirow{2}{*}{ Year } & \multirow{2}{*}{$\begin{array}{c}\text { Installed capacity of solar } \\
\text { power plants, MW }\end{array}$} & \multirow{2}{*}{$\begin{array}{c}\text { Number } \\
\text { new solar power } \\
\text { plants }\end{array}$} & \multicolumn{4}{|c|}{$\begin{array}{c}\text { Number of stations with a capacity } \\
\text { exceeding: }\end{array}$} \\
\cline { 4 - 7 } & & 494 & 114 & 25 & 9 & 5 \\
\hline 2017 & 3537,382 & 162 & 16 & 3 & 1 & 0 \\
\hline 2018 & 645,688 & 63 & 3 & 0 & 0 & 0 \\
\hline 2019 & 211,016 th most common & \multicolumn{4}{|c}{} \\
\hline
\end{tabular}


Average industrial capacitysolar power plants in 2019 is $7.16 \mathrm{MW}$, which is $3.17 \mathrm{MW}(79.4 \%)$ higher than in 2018 year.
The situation regarding the territorial distribution of industrial solar stations put into operation in 2019 is as follows (Fig. 6).

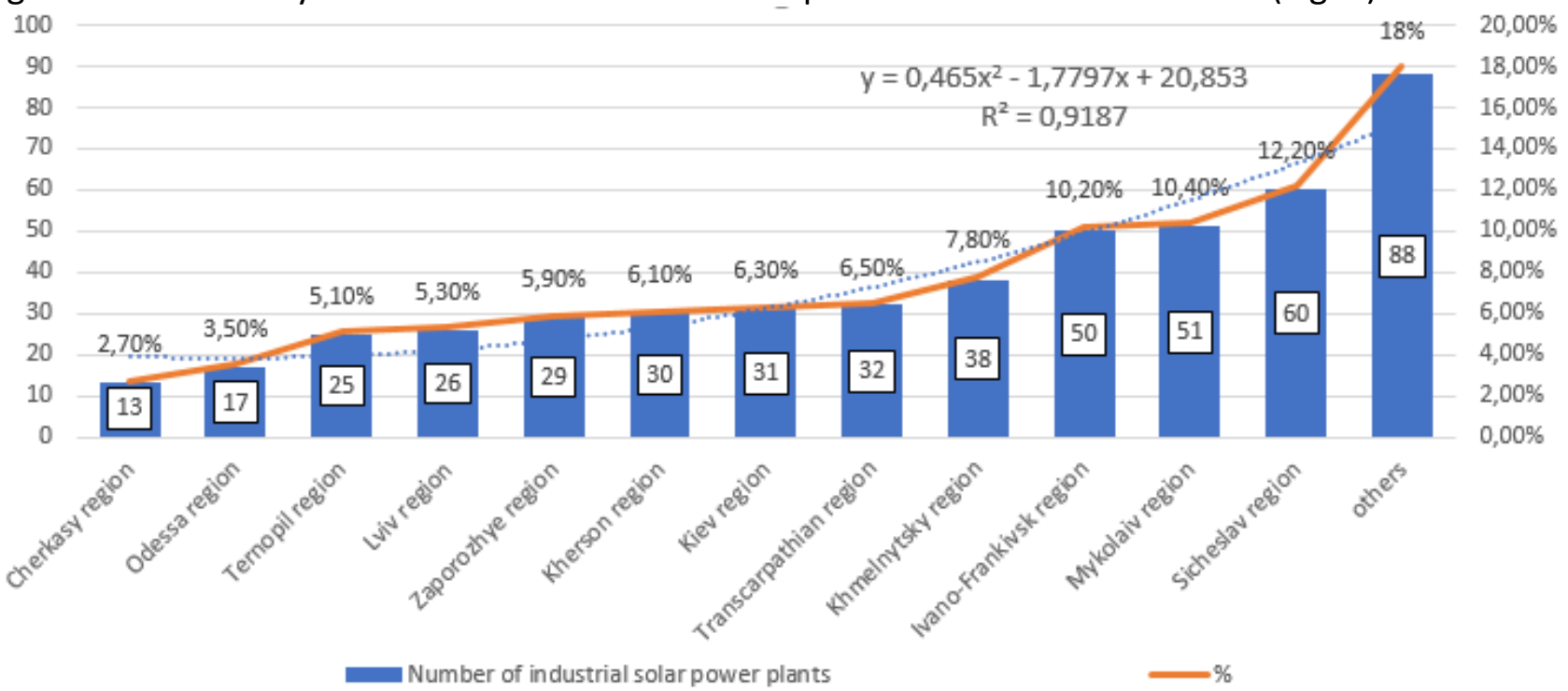

Figure 6 - The structure of the distribution of the number of industrial solar power plants in the regions that received in 2019 the 'green tariff'

In quantitative terms, the leader in terms of industrial solar power plants put into operation in 2019 was Sicheslav region (60 facilities, or 12.2\%). Mykolayivska and Ivano-Frankovska share the second and third places Frankivskareas with indicators of $10.4 \%$ and $10.2 \%$. The third position in the Khmelnytsky region - 7.8\%. In connection with the commissioning of two large facilities in the Nikopol region («Pokrovskaya» and "Nikopol» solar power plant) in the first place by a wide margin came Sicheslav region with a share of $27.1 \%$; in 2018 it occupied only 5 -tuposition. The second place behind the Nikolaev region where the total capacity of the implemented projects makes $14,3 \%$. On the third step - Zaporozhye region (5.9\%). Khmelnytsky and Kyiv regions with equal shares of $5.5 \%$ share the fourth and fifth places.

The leaders of the electricity industry in 2019, which exceeded the threshold of 30 million kWh, are presented in table. 3 .

Table 3 - Major manufacturers of solar electricity in Ukraine, 2019

\begin{tabular}{|c|c|c|}
\hline Name solar power plant and the region of its location & $\begin{array}{l}\text { The amount of } \\
\text { electricity generated in } \\
2019, \\
\text { million kW per year }\end{array}$ & $\begin{array}{l}\text { Installed power, } \\
\text { MW }\end{array}$ \\
\hline $\begin{array}{l}\text { SES "Nikopol", Sicheslav region, Nikopol district, Suburban } \\
\text { and Chkalovsk village councils }\end{array}$ & $\begin{array}{l}282,606 \text { th most } \\
\text { common }\end{array}$ & $\begin{array}{l}246,154 \text { th most } \\
\text { common }\end{array}$ \\
\hline SES in the Zaporozhye region, Tokmak & $\begin{array}{l}72,349 \text { th most } \\
\text { common }\end{array}$ & $\begin{array}{c}64.15 \\
\text { (10 launch } \\
\text { complexes) }\end{array}$ \\
\hline $\begin{array}{l}\text { SES "Kamyanets-Podilska", Khmelnytsky region, on the } \\
\text { territory of Panivets village council }\end{array}$ & $\begin{array}{l}71,674 \text { th most } \\
\text { common }\end{array}$ & 63,800 \\
\hline SES "Voskhod Solar", Berezanka township, Mykolaiv region & $\begin{array}{l}68,045 \text { th most } \\
\text { common }\end{array}$ & $\begin{array}{l}53,398 \text { th most } \\
\text { common }\end{array}$ \\
\hline SES "Yavoriv", Lviv region, Yavoriv district, village Ternovitsa & $\begin{array}{l}49,371 \text { th most } \\
\text { common }\end{array}$ & $\begin{array}{c}36,753+35,101 \\
(2019)\end{array}$ \\
\hline SES "Bolgrad Solar", Railway, Bolgrad district, Odessa region & $\begin{array}{l}44,901 \text { th most } \\
\text { common }\end{array}$ & 34.14 \\
\hline
\end{tabular}




\begin{tabular}{|c|c|c|}
\hline Name solar power plant and the region of its location & $\begin{array}{c}\text { The amount of } \\
\text { electricity generated in } \\
2019 \text {, } \\
\text { million kW per year }\end{array}$ & $\begin{array}{l}\text { Installed power, } \\
\text { MW }\end{array}$ \\
\hline SES "Priozerne 1", Kiliya, Odessa region. & $\begin{array}{l}37,611 \text { th most } \\
\text { common }\end{array}$ & $\begin{array}{l}27,356 \text { th most } \\
\text { common }\end{array}$ \\
\hline SES "Priozerne 2", Kiliya, Odessa region. & $\begin{array}{l}37,289 \text { th most } \\
\text { common }\end{array}$ & $\begin{array}{l}27,488 \text { th most } \\
\text { common }\end{array}$ \\
\hline $\begin{array}{l}\text { SES "Neptune Solar", Taborivka, Voznesensky district, the } \\
\text { Nikolaev area. }\end{array}$ & $\begin{array}{l}36,558 \text { th most } \\
\text { common }\end{array}$ & $\begin{array}{l}29,307 \text { th most } \\
\text { common }\end{array}$ \\
\hline SES, Kherson, the territory of the Kherson city council & $\begin{array}{l}33,046 \text { th most } \\
\text { common }\end{array}$ & $\begin{array}{l}34,758 \text { th most } \\
\text { common } \\
\text { ( } 2 \text { launch } \\
\text { complexes) }\end{array}$ \\
\hline
\end{tabular}

The leader is the station "Nikopol», the production of which is 282.606 million $\mathrm{kWh}$. In second place - 10 launch complexes in Tokmak - 72.349 million kWh. He occupies the third position "Kamianets - Podilskyi» SES with an indicator of 71.674 million kWh. Fourth place behind the station "Sunrise Solar" - 68.045 million kWh. On the fifth step - SES "Yavoriv» (49.371 million kWh), consisting of two complexes, one of which received "green tariff» in 2019. Thus, the generation of electricity by industrial solar power plants in 2019 almost three times exceeded the corresponding figure of Kakhovka hydroelectric power plant.

As of June 1, 2020 in Ukraine "green tariff» received 174 new SES, of which 99 - ground and 75 - installed on the roofs and walls of buildings and structures.

The total capacity of these SES is $686,016 \mathrm{MW}$ or $12.2 \%$ of the total figure determined for the country on that date $(5610,611 \mathrm{MW})$.

Since the implementation in 2020, 22 stations have a capacity exceeding $10 \mathrm{MW}, 6$ facilities have exceeded the threshold of 20 $\mathrm{MW}$, and four more have exceeded $30 \mathrm{MW}$. The largest SES for the first 5 months of this year were two stages of SES «Ingulets» - Mykolaiv region, Snihuriv district, the territory of Afanasiev village council, the total capacity of which is $57,552 \mathrm{MW}$.

Thus, 2019 demonstrated the rapid evolution of the segment of industrial solar power plants as a component of renewable energy. The transition to alternative energy sources for industrial enterprises is a rather complex technological task, which requires methodological developments for the optimization of energy resources to maximize the efficiency of enterprises.

Methods for assessing the efficiency of the enterprise in the transition to alternative (helio) energy sources

A method for assessing the efficiency of the enterprise in its transition to alternative (helio) energy sources based on the use of production functions and factor models, which include the entire evaluation apparatus and a set of indicators of efficiency (appropriateness) of resource use, i.e. resource conservation.

This method of assessing the performance of the enterprise is based on the use of the CobbDouglas production function, which allows to justify the decision on the feasibility of the use of production resources and to adjust the deviations of the spent resources from the normative values. The Cobb-Douglas model (1928) is a neoclassical two-factor model of the production function (Biddle, 2012).

To achieve the goal of the study, the transition from a two-factor model to a threefactor one is proposed.

It is proposed to divide the factors of an industrial enterprise into three blocks: labor $(L)$; capital investment $(K)$ and the unit of energy used (E). The production factors include the energy required to carry out the technological process. Energy costs account for a significant percentage of the cost of production. The 
formula takes the form:

$$
T C=P K^{\alpha} L^{\beta} E^{\psi}
$$

where

$T C$ - total costs of the enterprise are the sum of variable and fixed costs (total costs, TC)

$\mathrm{K}$ - capital;

$L$ - work;

E - energy used;

$\alpha$-indicator of the elasticity of production by capital, which characterizes the growth of product volume by $1 \%$ of capital growth;

$\beta-$ is an indicator of the elasticity of production at labor, which characterizes the growth of product volume by $1 \%$ of labor growth; $\psi$ - an indicator of the elasticity of production by energy used, which characterizes the growth of product volume by $1 \%$ growth of energy resources.

This approach is not unfounded and is acceptable under the following provisions. The classical concept of production growth assumes that within a production and economic system that uses natural and productive capital to carry out production and economic activities, production growth can be achieved by increasing the amount of resources consumed. Consider and present graphically this approach in the context of natural and productive capital (Fig. 7).

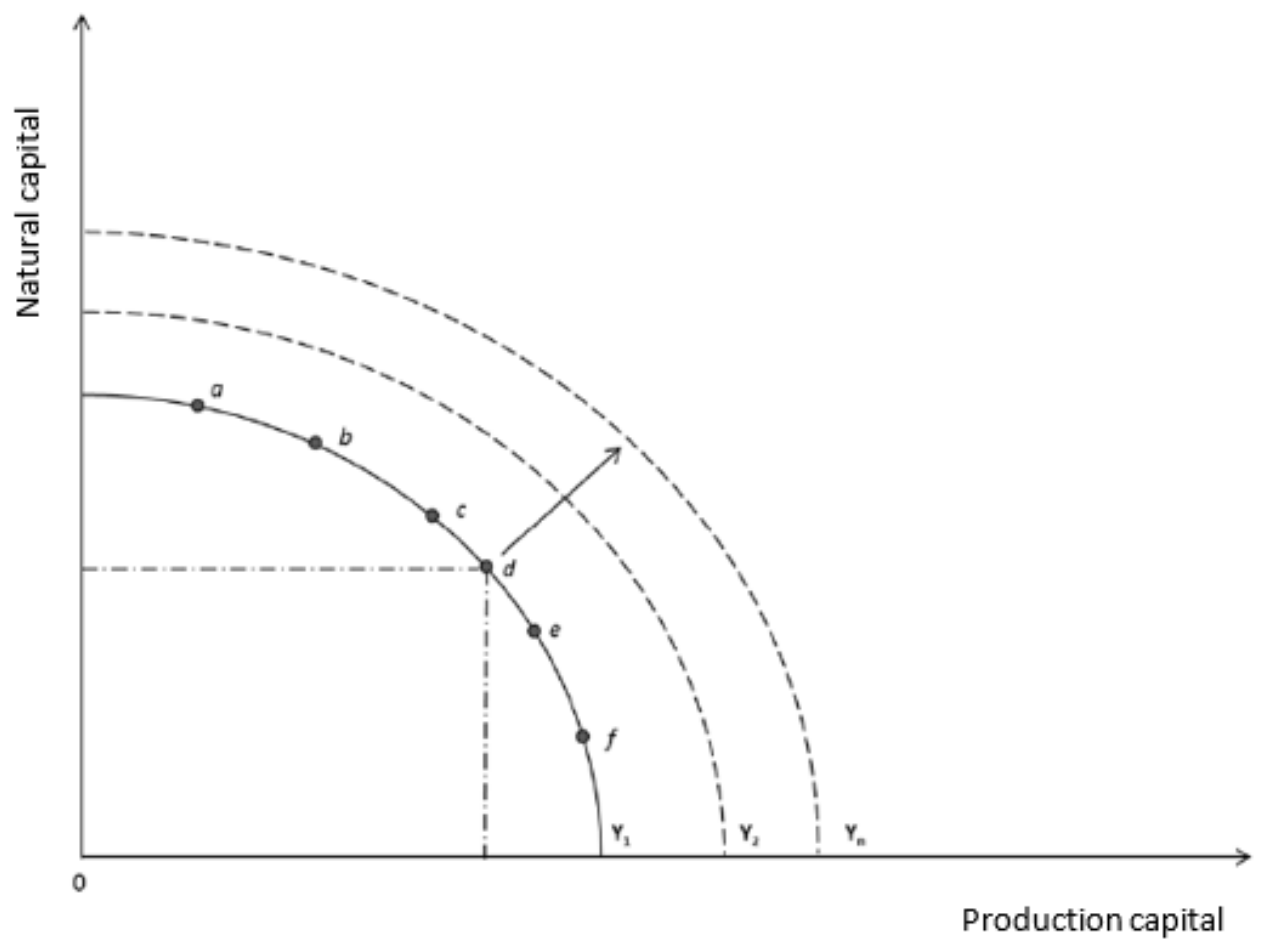

Figure 7-Graphic analytical model of production growth of the enterprise, taking into account the ratio of natural and productive capital

The curve $Y_{1}$ reflects a certain production and economic system, which is a set of possible options for the implementation of production and economic activities using natural and productive capital. That is $Y_{1}$, there are many points that characterize the various production combinations of the use of these resources $(a, b$, c, d ...). The curve $Y_{1}$ determines the optimal volume of production achievable at a given level of technology. The increase in production is possible with the expansion of technological potential. In Fig. 7, this transition is displayed as a shift of the curve $Y_{1}$ to the right up:

$$
Y_{1} \cdot \rightarrow Y_{2} \rightarrow Y_{n}
$$

According to the concept of sustainable development (Dean \& McMullen, 2007), while maintaining the quantity and quality of total capital, the priority of economic growth of the enterprise is to reduce the use of natural capital due to its limitations and depletion. Taking into account the need to preserve in time the total 
social capital, enterprise development, in the share of productive capital, determined addition to the need to reduce the consumption primarily by the level of technological of natural capital, also requires an increase in development (Fig. 8).

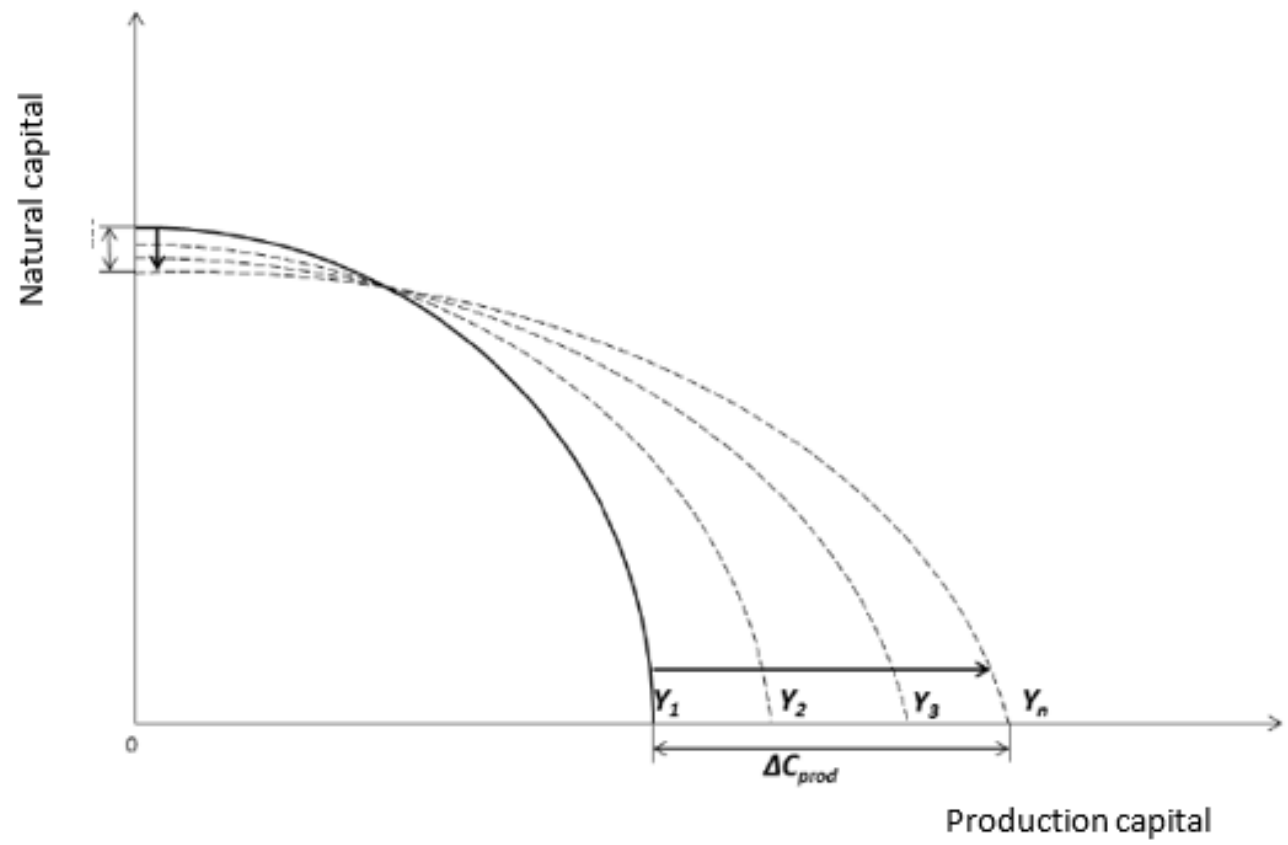

Figure 8-Graphic analytical model of production growth of the enterprise, according to the concept of sustainable development

According to the concept of sustainable development, the condition for the production growth of an industrial enterprise as a socioeconomic system is a reduction in the consumption of natural capital ( $\Delta$ Natural capital $<0)$ while increasing production capital $(\Delta$ Production capital>0).

Graphically, this is displayed as a shift of the curve $Y_{1}$ to the position $Y_{n}$ :

$$
Y_{1} \rightarrow Y_{2} \rightarrow Y_{3} \rightarrow Y_{n} .
$$

Obviously, such a problem can be solved only through the introduction of innovative resource efficiency technologies that reduce the consumption of non-renewable natural resources, while helping to increase the technological potential of the enterprise.

Application of the function Cobb-Douglas to assess the indicators of resource conservation of an industrial enterprise allows you to manage production costs, production volumes, profits of the enterprise and timely make management decisions to adjust production processes.

Fixed costs of the enterprise (time-fixed costs, TFC) are given by a constant $C$ :

$$
\boldsymbol{T F C}=C
$$

and variable costs (time-variable costs, TVC) take the form:

$$
\boldsymbol{T V} \boldsymbol{C}=B Q+A Q^{h}
$$

The formula for determining the total production costs, i.e. the total cost of production resources of the enterprise takes the following form:

$$
T C=C+B Q+A Q^{h}
$$

Enterprise profit (resource savings) PR is the difference between gross revenue (TR) (production function (1)) and total costs (4):

$$
P R=T R-T C=P Q^{\alpha}-C-B Q-A Q^{h}
$$

The total cost of resources of the enterprise in this case is expressed by the ratio:

$T C=A+B_{k} K+B_{L} L+B_{E} E+C_{k} K^{h}+C_{L} L^{d}+C_{E} E^{\psi}$

To ensure the necessary resource conservation, the task of maximizing output (1) in the presence of a fixed (optimal) level of resources expended:

$$
T C=V
$$

The company's profit is the difference between the production function and its total 
costs:

resource savings), it is advisable to use a method

$$
T R=P K^{\alpha} L^{\beta} E^{\psi}-V
$$

To maximize production (in the case of (Dopazo et al., 1967).

$$
L G=P K^{\alpha} L^{\beta} E^{\psi}+\lambda\left(A+B_{k} K+B_{L} L+B_{E} E+C_{k} K^{h}+C_{L} L^{d}+C_{E} E^{\psi}-V\right)
$$

The Lagrange multiplier method is generally Determine the extremum points of the function: used to find the conditional extremum.

$$
\left\{\begin{array}{c}
\frac{\partial L G}{\partial K}=P_{a} K^{a-1} L^{b} E^{\psi}+\lambda\left(B_{k}+C_{k} h K^{h-1}\right)=0 \\
\frac{\partial L G}{\partial L}=P_{b} K^{a-1} L^{b-1} E^{\psi}+\lambda\left(B_{L}+C_{L} d L^{d-1}\right)=0 \\
\frac{\partial L G}{\partial E}=P_{\psi} K^{a} L^{b} E^{\psi-1}+\lambda\left(B_{E}+C_{E} \psi E^{\psi-1}\right)=0 \\
\frac{\partial L G}{\partial \lambda}=A+B_{k} K+B_{L} L+B_{E} E+C_{k} K^{h}+C_{L} L^{d}+C_{E} E^{\psi}-V=0
\end{array}\right.
$$

Carrying out differentiation of equation (10), it is possible to estimate optimum (expedient) volumes of the spent resources and the maximum profit of the enterprise - for planning and forecasting of efficiency of the enterprise, on the basis of principles of resource saving.

Based on this model, the optimal parameters of the enterprise are determined, the influence of the parameter of the used energy resource on the efficiency of the enterprise is determined.

The introduction of this toolkit creates a basis for determining the optimal ratio of energy sources used, taking into account alternative (helio) energy sources.

A key feature of the introduction of energy efficiency in enterprises is the need for economic feasibility of such projects. Since 2017, the GIZ project 'Consulting of enterprises on energy efficiency' has been operating in Ukraine, within which enterprises of the bakery, dairy industry, machine building and production of non-metallic building materials are offered to conduct pilot energy efficiency measures. The pilot activities include three stages:

1. Detailed energy audit: selected companies within the project will receive a report with a list of economically and technically feasible energy saving solutions of the enterprise.

2. Development of cost-effective energy efficiency projects: based on the results of the energy audit, the selected companies will receive a clear plan for the implementation of energy-saving and cost-effective measures.

3. Support in project implementation: at this stage, GIZ experts will provide companies with engineering and consulting support in the implementation of projects developed in the previous stage.

In this case, any investment in the enterprise is considered in terms of its profitability. The accompanying issue is the sources of project financing and the cost of such capital. The financing of activities by enterprises is carried out with their own funds or borrowed funds. Usually companies attract commercial loans. The rate of return of the project must be higher than the cost of borrowed resources. The scheme of implementation of the energy efficiency project at the enterprise is presented in Fig. 9. 


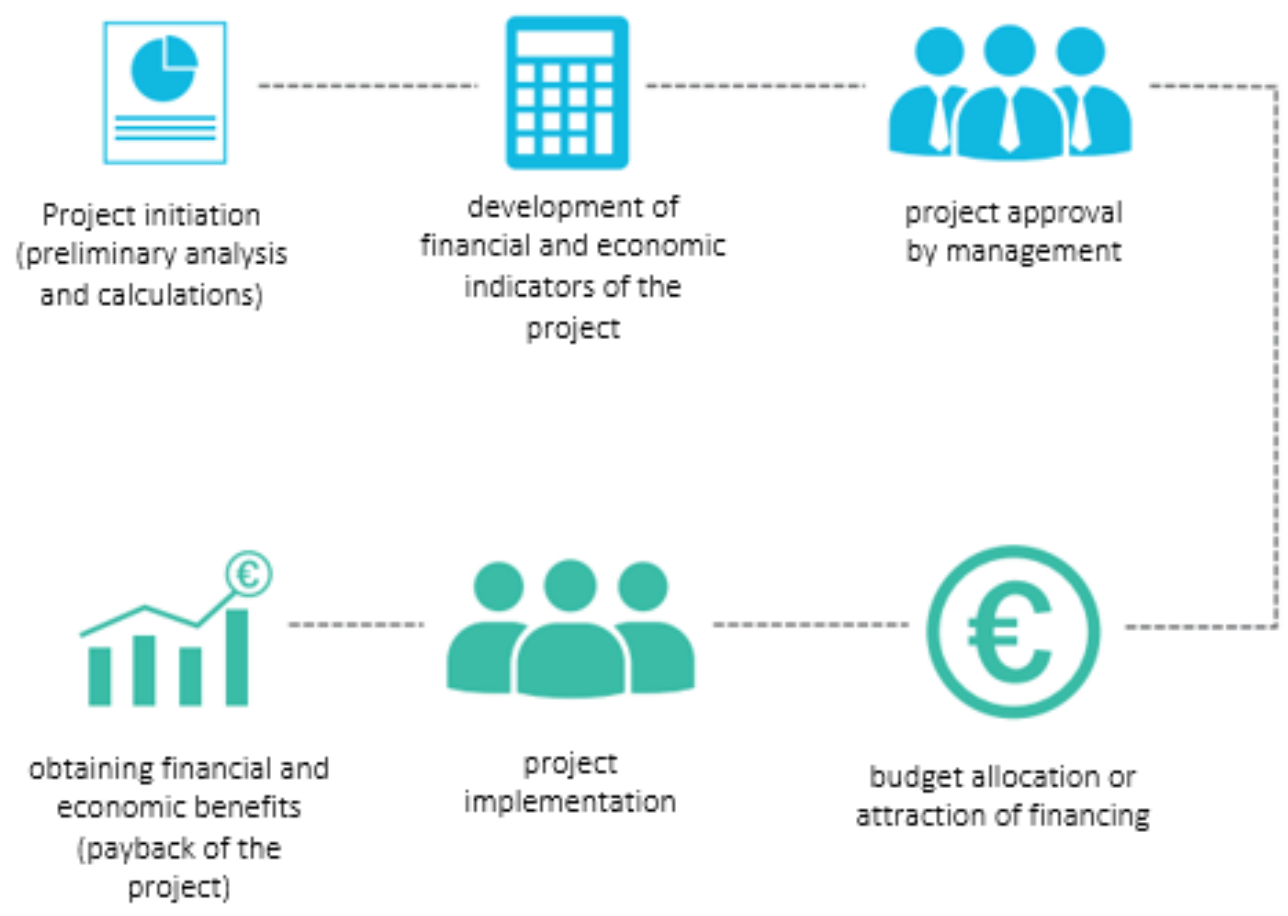

Figure 9 - Stages of the process of implementing an energy efficiency project at the enterprise

The key tools to support the implementation of energy efficiency reform are the introduction of commitments, taxes and penalties for noncompliance, on the one hand, and mechanisms to support energy efficiency, on the other. For example, in France, the 'polluter pays' principle has been implemented and a new 'environmental responsibility' has been introduced for companies. The 'polluter pays' principle is the responsibility of the operator

\section{Conclusions}

Alternative energy sources are seen as an important tool to reduce the environmental burden of energy production and consumption. Solar energy is one of the largest and most promising components of alternative energy. The study shows that 2019 demonstrated the rapid evolution of the segment of industrial solar power plants as a component of renewable energy.

The main reason for measures to reduce energy consumption at the enterprise is the need to increase the economic efficiency of production. The transition to alternative energy sources for industrial enterprises is a rather complex technological task, which requires methodological developments for the (natural or legal person, private or public person) for the environment in connection with their professional activities in the event of serious damage or imminent threat of serious damage to the environment.

Thus, the management of energy consumption of the enterprise is a system of measures to encourage energy efficiency, i.e. to ensure that the company's electricity costs do not exceed the environmental thresholds.

optimization of energy resources to maximize the efficiency of enterprises. A method for assessing the efficiency of the enterprise in its transition to alternative (helio) energy sources based on the use of production functions and factor models, which include the entire evaluation apparatus and a set of indicators of efficiency (appropriateness) of resource use, ie resource conservation. This method of assessing the performance of the enterprise is based on the use of the Cobb-Douglas production function, which allows to justify the decision on the feasibility of the use of production resources and to adjust the deviations of the spent resources from the normative values. 


\section{References}

Austin, J., Stevenson, H., and Wei-Skillern, J. (2006), "Social and Commercial Entrepreneurship: Same, different, or both?" Entrepreneurship Theory and Practice 30(1), 1-22.

Biddle, Jeff. 2012. "Retrospectives: The Introduction of the Cobb-Douglas Regression." Journal of Economic Perspectives, 26 (2): 223-36.

Bondarenko S.A., Zerkina O.O. (2019). SMART GRID as a basis for innovative transformations in the electricity market of Ukraine in the conditions of European integration processes. Business Inform. 4. 105-114.

Bondarenko Svitlana (2019). Smart grid in ensuring the intellectualization of the energy system of Ukraine. Social development \& Security. 9 (1), 26-39.

BP: Statistical Review of World Energy - 2020 edition. https://nangs.org/analytics/bpstatistical-review-of-world-energy

Ciara Ahern' Brian Norton (2020). Energy Performance Certification: Misassessment due to assuming default heat losses. Energy and Buildings. 224(1). https://www.sciencedirect.com/science/arti cle/pii/S037877882030880X

Cohen B., Winn M. I. (2007). Market imperfections, opportunity and sustainable entrepreneurship. Journal of Business Venturing. Issue 22. $29-49$.

Dean, T. J., and McMullen, J. S. (2007). "Toward a theory of sustainable entrepreneurship: Reducing environmental degradation through entrepreneurial action." Journal of Business Venturing 22, 50- 76.

Dopazo, J.F.; Klitin, O.A.; Stagg, G.W.; Watson, M. (1967). An optimization technique for real and reactive power allocation. Proc. IEEE, 55, 1877-1885.

Energy efficiency 101: what is energy efficiency? https://www.energysage.com/ energy-efficiency/101/

Energy management for business. https://www.energy.gov.au/business/energ $y$-management-business
Energy market, http://www.er.gov.ua/

Energy-intensive industries. Challenges and opportunities in energy transition. https://www.europarl.europa.eu/RegData/e tudes/STUD/2020/652717/IPOL_STU(2020)6 52717_EN.pdf

European industrial strategy. https://ec.europa.eu/info/strategy/priorities -2019-2024/europe-fit-digital-

age/european-industrial-strategy_en

Georgeson L., Maslin M., Poessinouw M. (2014). The global green economy: a review of concepts, definitions, measurement methodologies and their interactions. Gegraphy and Environment, 4(1). https://rgsibg.onlinelibrary.wiley.com/doi/p df/10.1002/geo2.36

Going Circular: how Global Business is embracing the Circular Economy. https://www.greenindustryplatform.org/site s/default/files/downloads/resource/newswe ek_vantage_going_circular_2018jan19.pdf

Intergovernmental Panel on Climate Change (IPCC). Climate Change 2007-Mitigation of Climate Change: Contribution of Working Group III to the Fourth Assessment Report of the IPCC. Cambridge University Press (2007). https://agris.fao.org/agrissearch/search.do?recordID=XF2008415344

J. Sathaye, S. Murtishaw (2004). Market Failures, Consumer Preferences, and Transaction Costs in Energy Efficiency Purchase Decisions. Public Interest Energy Research (PIER) Program, CA, USA. https://www.osti.gov/servlets/purl/91 9919

Letschert, V., Bojda, N., Ke, J., McNeil, M.A. (2012). Global Estimate of Cost-Effective Potential for Minimum Efficiency Performance Standards-Energy Savings, Environmental and Financial Impacts. Lawrence Berkeley National Laboratory Report LBNL-5723E. https://www.osti.gov/ servlets/purl/1223012

Lukaschuk Yu. A., Bem I., Levchenko OV (2018). Energy efficiency of pneumatic systems within the possibilities of the industrial 
revolution 4.0. Mechanics and Advanced Technologies. 2(83). 87-93.

McNeil, M. A., Letschert, V. E., de la Rue du Can, S. (2008). Global Potential of Energy Efficiency Standards and Labeling Programs. Lawrence Berkeley National Laboratory, for Ministry of Economy, Trade, and Industry (METI).

https://www.osti.gov/servlets/purl/935754

Murphy, L., Meier, F., 2011. Waking a Sleeping Giant: Policy Tools to Improve the Energy Performance of the Existing Housing Stock in The Netherlands. European Council for Energy-Efficient Economy, Summer Study 2011, La Colle Sur Loup, France. https://repository.tudelft.nl/islandora/objec t/uuid:c1f0c794-f094-4d4d-a2ed29aa53e62718
Promoting the improvement of environmental performance of small and medium enterprises. The main results of the survey. Recearch\&Branding Group. http://rb.com.ua/2015/

Ruzzenenti F, Font Vivanco D, Galvin R, Sorrell S, Wagner A and Walnum HJ (2019) Editorial: The Rebound Effect and the Jevons' Paradox: Beyond the Conventional Wisdom. Front. Energy Res. 7:90.

Solar energy: what you need to know. https://www.energysage.com/solar/

World Energy Investment 2020. https://www.iea.org/reports/world-energyinvestment-2020/key-

findings?utm_content=buffer47e92\&utm_m edium=social\&utm_source=twitter.com\&ut m_campaign=buffer 